Article

\title{
Correlates of University Students' Soft and Energy Drink Consumption According to Gender and Residency
}

\author{
Tom Deliens ${ }^{1, *}$, Peter Clarys ${ }^{1}$, Ilse De Bourdeaudhuij ${ }^{2}$ and Benedicte Deforche ${ }^{1,2}$ \\ ${ }^{1}$ Department of Human Biometry and Biomechanics, Vrije Universiteit Brussel, Pleinlaan 2, \\ Brussels 1050, Belgium; E-Mails: pclarys@vub.ac.be (P.C.); Benedicte.Deforche@ vub.ac.be (B.D.) \\ ${ }^{2}$ Department of Movement and Sports Sciences, Ghent University, Watersportlaan 2, Ghent 9000 , \\ Belgium; E-Mail: ilse.debourdeaudhuij@ugent.be \\ * Author to whom correspondence should be addressed; E-Mail: Tom.Deliens@ vub.ac.be; \\ Tel.: +322-629-2733.
}

Received: 29 June 2015 / Accepted: 31 July 2015 / Published: 6 August 2015

\begin{abstract}
This study assessed personal and environmental correlates of Belgian university students' soft and energy drink consumption and investigated whether these associations were moderated by gender or residency. Four hundred twenty-five university students completed a self-reported on-line questionnaire assessing socio-demographics, health status, soft and energy drink consumption, as well as personal and environmental factors related to soft and energy drink consumption. Multiple linear regression analyses were conducted. Students believing soft drink intake should be minimized (individual subjective norm), finding it less difficult to avoid soft drinks (perceived behavioral control), being convinced they could avoid soft drinks in different situations (self-efficacy), having family and friends who rarely consume soft drinks (modelling), and having stricter family rules about soft drink intake were less likely to consume soft drinks. Students showing stronger behavioral control, having stricter family rules about energy drink intake, and reporting lower energy drink availability were less likely to consume energy drinks. Gender and residency moderated several associations between psychosocial constructs and consumption. Future research should investigate whether interventions focusing on the above personal and environmental correlates can indeed improve university students' beverage choices.
\end{abstract}

Keywords: determinants; sugar sweetened beverages; soda; caffeinated beverages; moderators; college 


\section{Introduction}

Sugar sweetened beverage consumption (including the full range of soft drinks, fruit drinks, sports drinks) has increased considerably across the globe during the last decades [1,2]. Malik's review [1] clearly showed that sugar sweetened beverage intake significantly contributes to weight gain and can lead to increased risk of type 2 diabetes and cardiovascular disease. Sugar sweetened beverages, typically containing sucrose, high-fructose corn syrup, or fruit juice concentrates, may lead to weight gain through the high added sugar content, low satiety, and potential incomplete compensation for total energy, leading to increased energy intake [1]. Today, it is also hypothesized that artificially sweetened beverage consumption may be related to weight gain, diabetes, and cardiovascular disease. Due to a dysregulation of appetite control, as a consequence of the mismatch between the intense taste of sweetness during consumption and the lack of energy consumed, artificially sweetened beverages may increase weight [3]. Furthermore, studies have demonstrated an effect of artificial sweeteners and diet beverages on incretin hormones, which would influence insulin secretion and thus blood glucose control [3]. Accordingly, consumption of artificially sweetened beverages has been associated with an increased risk for diabetes [4].

Similar to soft drinks, the consumption of energy drinks has increased markedly during the last two decennia [5-7]. Along with the exponential growth of the energy drink market [5], there are also increasing concerns regarding the potential health effects of energy drink consumption [7]. Energy drinks (Red Bull, Nalu, Burn, Monster) are known to stimulate cognitive functioning and alertness and typically contain large doses of stimulants, such as caffeine (ranging from 50 to $505 \mathrm{mg}$ per can or bottle), taurine, guarana, but also sucrose, B vitamins, sodium, and other minerals [2,5,8]. Sucrose and caffeine containing drinks are thought to play a role in the epidemic of obesity and type 2 diabetes [9,10]. Although caffeine generally increases fat oxidation [11] and may even have a positive effect on long-term weight management when combined with ephedrine [12], Rush and colleagues [13] showed that combining sucrose and caffeine (in the form of energy drinks) may increase carbohydrate oxidation and suppress fat oxidation. It was also suggested that energy drink consumption may even cause lipogenesis [13]. Furthermore, caffeine may act as an adenosine receptor antagonist and lowers glucose uptake, proposing that skeletal muscle becomes more resistant to insulin with the administration of caffeine [14].

Current recommendations are to limit total soft drink (sugar and artificially sweetened beverages) and energy drink consumption and replace them with healthy alternatives such as water [1,3].

Previous research has shown that going to college or university can be a critical period for unhealthy weight related behaviors including sweetened beverage consumption $[15,16]$. University and college students are heavy consumers of sugar sweetened beverages. Sixty-five percent of students reported daily consumption of some form of sugar sweetened beverages, with an estimated caloric intake of $543 \pm 671 \mathrm{kCal} /$ day [17]. Also energy drinks are very popular in this particular population. In the US, up to $59 \%$ of college students reported energy drink consumption during the last week, whereas $29 \%$ of students consumed one or more energy drinks the day before completing the survey [18]. Among Turkish students, $10.3 \%$ of current energy drink users reported daily intake [19]. Moreover, males were more likely than females to consume sugar sweetened beverages and energy drinks daily [17,18,20]. Although Brunt and colleagues [21] showed that beverage intake among college students may vary according 
to residency, however, to date, no studies have assessed the association between residency and soft and energy drink consumption. Previous studies mainly focused on consumption of sugar sweetened beverages alone, rather than total (sugar and artificially sweetened) soft drink consumption. To the best of our knowledge, no European data on energy drink consumption in university students exist.

To develop effective and tailored intervention strategies aiming to decrease university students' soft and energy drink intake, it is important to get insight into factors associated with students' consumption. Focus groups in six US colleges revealed that taste was the most important reason for choosing a non-alcoholic beverage, whereas price was the second most commonly mentioned factor influencing choice [22]. According to the same study, health and nutritional content of beverages had limited influence on choice [22]. Another focus group study in Australian university students reported that non-alcoholic beverage consumption was related to some social cues (setting in which alcohol is usually consumed, socializing with friends, and family influences), and some physical environmental cues (purchasing of fast foods, and ready availability, pricing and promotion of caloric beverages) [23]. Furthermore, other intrinsic qualities (such as sugar and caffeine content, and their association with treats and rewards) and personal health beliefs were also seen as important influences on consumption [23]. More specifically for caffeinated beverages, non-European literature showed that students may consume energy drinks to keep awake, to increase energy, to boost performance during exercise, to concentrate while studying, and to drink with alcohol while partying [19,20,24]. Apart from the abovementioned reasons or motivations to drink energy drinks, to date no correlates of energy drink consumption have been assessed from a multilevel (combining personal with social and physical environmental factors) behavioral viewpoint.

To the best of our knowledge, only qualitative studies [22,23] assessing determinants or correlates of university students' soft drink consumption have been conducted. Quantitative studies are needed in order to explain to what extent personal and environmental factors are associated with soft drink consumption among university students. Moreover, no European studies have assessed correlates of energy drink consumption in this population. Although studies have shown that university students' weight related behaviors may vary according to gender and residency [17,21], to date, no studies have assessed whether personal and environmental correlates of soft drink consumption differ by gender or residency. Including gender and residency as possible moderators may potentially yield important information on whether specific subgroups of students should be approached differently when designing intervention strategies. Therefore, the first objective of this study was to assess which personal and environmental factors were related to Belgian university students' soft drink and energy drink consumption. The second objective was to investigate whether these associations were moderated by gender or residency.

\section{Experimental Section}

\subsection{Participants}

A random sample of 816 university students (including students of all study years) was contacted face-to-face on the university campus. All contacted students orally consented to participate in the study and received an on-line questionnaire invitation by e-mail. Two reminder e-mails were sent to every 
student. Four hundred sixty-seven (57.2\%) students completed the questionnaire, with 425 of them $(52.1 \%)$ completing the questionnaire entirely.

\subsection{Procedure}

In this cross-sectional study, students were asked to complete a self-reported on-line questionnaire consisting of questions derived from existing questionnaires [25-30]. The aim was to assess socio-demographic variables, health status, soft and energy drink consumption (see Table 1), as well as personal and environmental factors related to soft and energy drink consumption (see Table 2).

Table 1. Sample characteristics and students' beverage consumption (\%, Mean \pm SD).

\begin{tabular}{|c|c|}
\hline$n=425$ & $\%$, Mean \pm SD \\
\hline \multicolumn{2}{|l|}{ Demographics } \\
\hline Gender ( $\%$ females) & 59.8 \\
\hline Age (years) & $21.2 \pm 2.1$ \\
\hline Ethnicity ( $\%$ of students of which one of the parents is from foreign origin) & 29.6 \\
\hline Residency (\% living in a student residence) & 36.3 \\
\hline \multicolumn{2}{|l|}{ Socio Economic Status (SES) } \\
\hline Education mother (\% diploma higher education) & 61.0 \\
\hline Education father (\% diploma higher education) & 61.7 \\
\hline \multicolumn{2}{|l|}{ General health } \\
\hline BMI $\left(\mathrm{kg} / \mathrm{m}^{2}\right)$ & $21.8 \pm 2.9$ \\
\hline Underweight (\%) & 9.5 \\
\hline Normal weight (\%) & 78.7 \\
\hline Overweight (\%) & 10.4 \\
\hline Obese $(\%)$ & 1.4 \\
\hline Smoking (\% non-smokers) & 87.3 \\
\hline Perceived health (\% reporting good to very good health) & 75.0 \\
\hline Perceived fitness (\% reporting good to very good fitness) & 43.9 \\
\hline \multicolumn{2}{|l|}{ Beverage consumption } \\
\hline Total soft drink consumption (mL/day) & $423.6 \pm 445.2$ \\
\hline Sugar sweetened carbonated beverages (mL/day) & $219.3 \pm 352.4$ \\
\hline Artificially sweetened carbonated beverages (mL/day) & $75.9 \pm 194.3$ \\
\hline Orange juice (mL/day) & $69.1 \pm 110.7$ \\
\hline Other juices (mL/day) & $41.3 \pm 92.1$ \\
\hline Sports drinks (mL/day) & $18.6 \pm 44.8$ \\
\hline Total energy drink consumption (mL/day) & $19.9 \pm 62.4$ \\
\hline Sugar sweetened energy drinks (mL/day) & $17.2 \pm 59.0$ \\
\hline Artificially sweetened energy drinks (mL/day) & $2.7 \pm 14.1$ \\
\hline Water (mL/day) & $649.9 \pm 270.9$ \\
\hline
\end{tabular}


Table 2. Personal and environmental factors of soft and energy drink consumption (Mean $\pm \mathrm{SD} ; n=425$ ).

\begin{tabular}{|c|c|c|c|c|}
\hline $\begin{array}{c}\text { Variable name } \\
\text { (number of items) } \#\end{array}$ & Content & Scoring & $\begin{array}{l}\text { Soft drinks } \\
\text { Mean } \pm \text { SD }\end{array}$ & $\begin{array}{c}\text { Energy drinks } \\
\text { Mean } \pm \text { SD }\end{array}$ \\
\hline \multicolumn{5}{|l|}{ Personal factors } \\
\hline $\begin{array}{c}\text { Taste } \\
\text { preference }(1)^{\mathrm{a}}\end{array}$ & $\begin{array}{c}\text { How tasty are soft/ } \\
\text { energy drinks to you? }\end{array}$ & $\begin{array}{c}0=\text { not tasty at all } \\
10=\text { very tasty }\end{array}$ & $6.6 \pm 1.9$ & $4.3 \pm 3.0$ \\
\hline Attitude (1) ${ }^{\mathrm{b}}$ & $\begin{array}{l}\text { How do you feel about drinking } \\
\text { soft/energy drinks? Drinking } \\
\text { soft/energy drinks is: ... }\end{array}$ & $\begin{array}{l}1=\text { very bad; } \\
5=\text { very good }\end{array}$ & $2.4 \pm 0.7$ & $1.9 \pm 0.7$ \\
\hline $\begin{array}{l}\text { Individual subjective } \\
\text { norm (1) }\end{array}$ & $\begin{array}{l}\text { I believe I should avoid drinking } \\
\text { soft/energy drinks on most days } \\
\text { of the week }\end{array}$ & $\begin{array}{c}1=\text { strongly } \\
\text { disagree; } \\
5=\text { strongly agree }\end{array}$ & $3.7 \pm 1.2$ & $4.5 \pm 0.8$ \\
\hline $\begin{array}{c}\text { Perceived } \\
\text { control (2) }{ }^{\mathrm{c}}\end{array}$ & $\begin{array}{c}\text { How hard is it to avoid drinking } \\
\text { soft/energy drinks at home/ } \\
\text { at university? }\end{array}$ & $\begin{array}{c}1=\text { very hard; } \\
5=\text { not hard at all }\end{array}$ & $3.7 \pm 1.0$ & $4.6 \pm 0.8$ \\
\hline Habit strength (3) ${ }^{d}$ & $\begin{array}{l}\text { Drinking soft/energy drinks is } \\
\text { something that I almost } \\
\text { automatically do/I regularly } \\
\text { do/typically me }\end{array}$ & $\begin{array}{c}1=\text { strongly } \\
\text { disagree; } \\
5=\text { strongly agree }\end{array}$ & $2.5 \pm 1.2$ & $1.4 \pm 0.8$ \\
\hline $\begin{array}{l}\text { Self-efficacy } \\
\quad(11 / 13)^{c}\end{array}$ & $\begin{array}{l}\text { Confidence to avoid soft/energy } \\
\text { drinks in potentially difficult } \\
\text { situations (e.g. if you are going } \\
\text { out, during exams) }\end{array}$ & $\begin{array}{l}1=\text { I know for sure } \\
\text { I cannot; } 5=\mathrm{I} \\
\text { know for sure I can }\end{array}$ & $3.7 \pm 0.8$ & $4.4 \pm 0.8$ \\
\hline $\begin{array}{c}\text { Perceived } \\
\text { benefits }(9 / 11)^{c}\end{array}$ & $\begin{array}{l}\text { Agreement with positive effects } \\
\text { of avoiding soft/energy drinks } \\
\text { (e.g. healthy, spending less } \\
\text { money, no palpitations) }\end{array}$ & $\begin{array}{c}1=\text { strongly } \\
\text { disagree; } \\
5=\text { strongly agree }\end{array}$ & $3.4 \pm 0.7$ & $3.5 \pm 0.9$ \\
\hline $\begin{array}{c}\text { Perceived } \\
\text { barriers }(12 / 15)^{\mathrm{c}}\end{array}$ & $\begin{array}{c}\text { Agreement with possible } \\
\text { barriers to avoid drinking } \\
\text { soft/energy drinks (e.g. lack of } \\
\text { self-discipline, temptation) }\end{array}$ & $\begin{array}{c}1=\text { strongly } \\
\text { disagree; } \\
5=\text { strongly agree }\end{array}$ & $2.0 \pm 0.7$ & $1.8 \pm 0.8$ \\
\hline \multicolumn{5}{|l|}{$\begin{array}{l}\text { Environmental } \\
\text { factors }\end{array}$} \\
\hline Social norm $(3)^{\mathrm{c}}$ & $\begin{array}{c}\text { Do(es) your } \\
\text { partner/parents/friends believe } \\
\text { you should avoid drinking } \\
\text { soft/energy drinks on most days } \\
\text { of the week? }\end{array}$ & $\begin{array}{c}1=\text { not at all } \\
5=\text { totally }\end{array}$ & $2.8 \pm 0.9$ & $2.7 \pm 1.3$ \\
\hline
\end{tabular}


Table 2. Cont.

\begin{tabular}{|c|c|c|c|c|}
\hline $\begin{array}{c}\text { Variable name } \\
\text { (number of items) } \#\end{array}$ & Content & Scoring & $\begin{array}{l}\text { Soft drinks } \\
\text { Mean } \pm \text { SD }\end{array}$ & $\begin{array}{c}\text { Energy drinks } \\
\text { Mean } \pm \text { SD }\end{array}$ \\
\hline Social support (3) ${ }^{\mathrm{c}}$ & $\begin{array}{l}\text { Do(es) your partner/parents/friends } \\
\text { support you (or would support you if } \\
\text { you would try) to avoid drinking soft/ } \\
\text { energy drinks on most days } \\
\text { of the week? }\end{array}$ & $\begin{array}{l}1 \text { = never; } \\
5=\text { very } \\
\text { often }\end{array}$ & $3.0 \pm 1.1$ & $3.3 \pm 1.3$ \\
\hline Modelling (3) ${ }^{c}$ & $\begin{array}{c}\text { How often do(es) your } \\
\text { partner/parents/friends drink } \\
\text { soft/energy drinks? }\end{array}$ & $\begin{array}{l}1 \text { = never } \\
5=\text { daily }\end{array}$ & $3.5 \pm 0.9$ & $2.0 \pm 0.7$ \\
\hline Family rules (2) b & $\begin{array}{l}\text { How often were you (earlier)/ } \\
\text { are you (now) allowed to drink } \\
\text { soft/energy drinks at home? }\end{array}$ & $\begin{array}{l}1=\text { never } \\
5=\text { always }\end{array}$ & $3.6 \pm 1.0$ & $2.2 \pm 1.3$ \\
\hline $\begin{array}{c}\text { Perceived } \\
\text { availability (5) }\end{array}$ & $\begin{array}{l}\text { To what extent are soft/energy drinks } \\
\text { available at home or student residence/ } \\
\text { in on-campus vending machines/in the } \\
\text { student restaurant/in on-campus } \\
\text { cafeterias/in campus surroundings? }\end{array}$ & $\begin{array}{l}1=\text { never } \\
5=\text { always }\end{array}$ & $4.5 \pm 0.5$ & $3.2 \pm 1.1$ \\
\hline $\begin{array}{l}\text { Distance to } \\
\text { stores (2) }\end{array}$ & $\begin{array}{l}\text { How far is it from home/student } \\
\text { residence to the nearest place or store } \\
\text { where you can buy soft/energy drinks? }\end{array}$ & $\begin{array}{c}1=\text { less } \\
\text { than } 50 \mathrm{~m} ; \\
7=\text { more } \\
\text { than } 10 \mathrm{~km}\end{array}$ & $3.2 \pm 1.3$ & $3.2 \pm 1.3$ \\
\hline
\end{tabular}

\# All variables were calculated by averaging the scores on the items included; a Bere et al. [27];

b Ezendam et al. [29]; ${ }^{\mathrm{c}}$ Vandelanotte et al. [26]; ${ }^{\mathrm{d}}$ Verplanken \& Orbell [25].

\subsection{Personal and Environmental Correlates}

The questionnaire included questions based on factors derived from psychosocial models used to explain health behavior, namely, Theory of Planned Behavior [31] and Social Cognitive Theory [32] and was completed with psychosocial and physical environmental questions based on results of previous focus group research in university students [22,23,33]. In the current study, all items representing psychological constructs were categorized as "personal factors", whereas all social and physical environmental items were categorized as 'environmental factors'. More details on how every item was measured are presented in Table 2.

\subsection{Beverage Consumption}

Soft drink consumption was defined as consumption of sugar sweetened (Coca-Cola, Fanta, Atlanta, GA, USA) and artificially sweetened carbonated beverages (Coca-Cola light, Fanta light), orange and other fruit juices, and sports drinks. Energy drink consumption was defined as consumption of caffeinated sugar or artificially sweetened carbonated beverages (Red Bull (light), Salzburg, Austria, Nalu). To measure daily soft and energy drink consumption (in $\mathrm{mL}$ ) participants were asked to answer the following question, derived from a validated food frequency questionnaire (FFQ) [28]: "How often do you consume the following beverages: (1) Coca-Cola, Fanta, Sprite, Ice Tea, or other sugar sweetened 
carbonated beverages; (2) Coca-Cola light/zero, Fanta light/zero, Sprite light/zero, Ice Tea light or other artificially sweetened carbonated beverages; (3) orange juice, fresh or non-fresh; (4) other juices; (5) Aquarius, AA Drink, or other sports drinks; (6) Red Bull, Nalu, Burn, Monster or other sugar sweetened energy drinks; (7) Red Bull light or other artificially sweetened energy drinks; (8) water (of any kind). For every item the following frequency categories were used: (1) never; (2) one to three times per month; (3) one time per week; (4) two to four times per week; (5) five to six times per week; (6) once a day; (7) two to three times per day; (8) four to six times per day; (9) more than six times per day. Missing frequencies were set to zero. To calculate beverage consumption, frequency (per day) was multiplied by a standard portion size (sugar and artificially sweetened carbonated beverages, and sports drinks $=330 \mathrm{~mL}$; orange juice and other juices $=200 \mathrm{~mL}$; energy drinks (regular and diet) $=250 \mathrm{~mL}$; water $=150 \mathrm{~mL}$ ) [34]. To calculate total soft drink consumption, sugar and artificially sweetened carbonated beverages, orange and other juices, and sports drinks were summed. To calculate total energy drink consumption, regular and diet energy drinks were summed.

\subsection{Ethics Statement}

All participants voluntarily completed an on-line questionnaire anonymously. The study was approved by the Medical Ethical Committee of the university hospital (Vrije Universiteit Brussel, Brussels, Belgium) on 5 October 2011 (B.U.N. 143201111941). All procedures followed were in accordance with the ethical standards of the responsible committee on human experimentation (institutional and national) and with the Helsinki Declaration of 1975, as revised in 2000.

\subsection{Statistical Analyses}

Data were analyzed using IBM SPSS Statistics 22. Independent samples $t$-tests and $c h i^{2}$-tests were used to compare basic characteristics of respondents excluded from the sample (students who did not complete the questionnaire entirely) with basic characteristics of the study sample. After checking for multicollinearity $(r>0.6)$, multiple linear regression analyses were conducted to determine factors related to soft and energy drink consumption. Firstly, a model that included the main effects of personal and environmental factors and potential moderators (gender and residency) was estimated. Secondly, different models were estimated which included the main effects and the interaction effect between the independent variables (personal and environmental factors) and one of the two moderators. Thirdly, a final model was built that combined the main effects with all significant interactions observed in the previous step. Significant interaction terms were explored according to established procedures [35]. Age, ethnicity, parental education, and body mass index (BMI) were included as covariates in all analyses. For main effects $p<0.05$ were considered as statistically significant. As interaction effects have less power, significance was set at $p<0.1$ to estimate significant interaction effects [36].

\section{Results}

\subsection{Comparison of Excluded Respondents with the Study Sample}

Basic characteristics of respondents excluded from the sample (students who did not complete the questionnaire entirely) were compared with basic characteristics of the study sample. The study sample 
$(n=425)$ and excluded respondents $(n=42)$ did not differ for gender $(59.8 v s .65 .9 \%$ female respondents; $\left.c h i^{2}=0.6 ; p=0.450\right)$, age $(21.2 \pm 2.1$ vs. $21.8 \pm 2.4$ years; $t=1.6 ; p=0.111)$ and BMI $(21.8 \pm 3.0 v s$. $\left.21.8 \pm 2.9 \mathrm{~kg} / \mathrm{m}^{2} ; t=-0.1 ; p=0.933\right)$.

\subsection{Sample Characteristics}

The sample consisted of $59.8 \%$ female respondents with a mean age of $21.2 \pm 2.1$ years. About one-third resided in a student residence. Total soft drink consumption was $423.6 \pm 445.2 \mathrm{~mL} /$ day, whereas total energy drink consumption was $19.9 \pm 62.4 \mathrm{~mL} /$ day. Additional sample characteristics are presented in Table 1.

\subsection{Personal and Environmental Correlates of Soft and Energy Drink Consumption}

Table 2 gives an overview of potential personal and environmental correlates of soft and energy drink consumption in Belgian university students with reference to the original questionnaires.

Table 3 shows the multivariate regression model of personal and environmental correlates of soft drink consumption in Belgian university students. After checking for multicollinearity (showing $r=-0.63$ between perceived behavioral control and habit strength) habit strength was excluded from the multiple regression model. After controlling for age, ethnicity, parental education, and BMI, perceived behavioral control was negatively related to soft drink consumption; the more students found it difficult to avoid soft drinks, the higher their soft drink consumption. Self-efficacy towards avoiding soft drinks was negatively associated with soft drink intake; the more students were convinced they can avoid soft drinks in different situations, the lower students' soft drink consumption. The main effects of individual subjective norm and modelling were moderated by residency, whereas the main effect of family rules was moderated by gender. Individual subjective norm towards avoiding soft drink consumption was negatively associated with soft drink consumption in students living at home $(\beta=-0.345 ; p<0.001)$; the more students living at home were convinced they should minimize their soft drink intake, the less these students drank soft drinks. No main effect of individual subjective norm was found in students living in a student residence $(\beta=-0.156 ; p=0.090)$. Modelling of soft drink consumption was positively associated with soft drink intake in students living at home $(\beta=0.186 ; p=0.005)$, but not in students living in a student residence ( $\beta=-0.026 ; p=0.781)$; the more students' partner, parents and friends or student colleagues drank soft drinks, the higher students' soft drink consumption. Family rules about soft drink intake was positively associated with soft drink consumption in male students $(\beta=0.234 ; p=0.009)$; the more male students were/are allowed (by their parents) to drink soft drinks, the higher their soft drink intake. No main effect of family rules was detected in female students $(\beta=0.045 ; p=0.556)$. Finally, education of the father (control variable) was also negatively related to soft drink consumption; the higher fathers' educational level, the lower students' soft drink consumption. The strongest correlate was individual subjective norm ( $\beta=-0.345 ; p<0.001)$. The total model explained $44.7 \%$ of the variance in soft drink consumption. 
Table 3. Multivariate regression model of personal and environmental correlates of soft drink consumption in Belgian university students ( $t$-values, $\beta$-values, Adjusted $R^{2}$ ).

\begin{tabular}{|c|c|c|c|}
\hline$n=425$ & $t$ & $\beta$ & $\operatorname{Adj} R^{2}$ \\
\hline \multicolumn{4}{|l|}{ Control variables } \\
\hline Age & -1.3 & -0.058 & \\
\hline Ethnicity $(0=$ parents from Belgian origin; $1=$ one of parents from foreign origin $)$ & 0.4 & 0.018 & \\
\hline Education mother $(0=$ no diploma higher education; $1=$ diploma higher education $)$ & -0.1 & -0.006 & \\
\hline Education father $(0=$ no diploma higher education; 1 = diploma higher education $)$ & $-2.8 * *$ & -0.129 & \\
\hline BMI & -1.5 & -0.070 & \\
\hline \multicolumn{4}{|l|}{ Moderators } \\
\hline Gender $(0=$ male; 1 = female $)$ & 1.3 & 0.220 & \\
\hline Residency $(0=$ living at home; $1=$ living in a student residence $)$ & 0.1 & 0.027 & \\
\hline \multicolumn{4}{|l|}{ Personal and environmental correlates } \\
\hline Taste preference & 0.0 & 0.001 & \\
\hline Attitude & 0.2 & 0.008 & \\
\hline Individual subjective norm & $\begin{array}{l}-4.8 \\
* * *\end{array}$ & -0.345 & \\
\hline Perceived control & $-2.2 *$ & -0.125 & \\
\hline Self-efficacy & $\begin{array}{l}-4.2 \\
* * *\end{array}$ & -0.239 & \\
\hline Perceived benefits & -0.3 & -0.017 & \\
\hline Perceived barriers & -0.8 & -0.042 & \\
\hline Social norm & $1.7^{\wedge}$ & 0.077 & \\
\hline Social support & 0.0 & 0.001 & \\
\hline Modelling & $2.9 * *$ & 0.186 & \\
\hline Family rules & $2.6 * *$ & 0.234 & \\
\hline Perceived availability & 1.6 & 0.075 & \\
\hline Distance to stores & 0.6 & 0.026 & \\
\hline \multicolumn{4}{|l|}{ Moderation effects of gender and residency } \\
\hline Individual subjective norm $\mathrm{x}$ residency & $1.7^{\wedge}$ & 0.311 & \\
\hline Perceived benefits $\mathrm{x}$ residency & 0.4 & 0.129 & \\
\hline Modelling x residency & $-1.9^{\wedge}$ & -0.411 & \\
\hline Family rules $\mathrm{x}$ gender & $-2.1 *$ & -0.345 & \\
\hline \multirow[t]{2}{*}{ Family rules $\mathrm{x}$ residency } & -0.6 & -0.111 & \\
\hline & & & 0.447 \\
\hline
\end{tabular}

$* p<0.05, * * p<0.01, * * * p<0.001, \wedge p<0.1, \alpha=0.05$

Table 4 shows the multivariate regression model of personal and environmental correlates of energy drink consumption in Belgian university students. After checking for multicollinearity (showing $r=-0.69$ between perceived behavioral control and habit strength) habits strength was excluded from the multiple regression model. After controlling for age, ethnicity, parental education, and BMI, both gender and residency were found to moderate the relationship between perceived behavioral control and energy drink consumption. In male students, perceived control was negatively associated with energy drink intake $(\beta=-0.820 ; p<0.001)$; the more male students found it difficult to avoid energy drinks, the higher their energy drink consumption. In females, no relation between perceived control and energy 
drink intake $(\beta=-0.212 ; p=0.141)$ was detected. Although in both students living at home and students living in a student residence perceived control was negatively associated with energy drink consumption, the association was stronger in students living at home $(\beta=-0.820 ; p<0.001)$ than in students living in a student residence $(\beta=-0.577 ; p<0.001)$. Both family rules and perceived availability correlated positively with energy drink consumption; the more students were/are allowed to drink energy drinks at home, and the more students report that energy drinks are available at home/at university, the higher their energy drink intake. Gender (control variable) was negatively associated with energy drink consumption, i.e. female students consumed less energy drinks than their male counterparts. Perceived control was the strongest correlate of energy drink consumption $(\beta=-0.820 ; p<0.001)$. The total model explained $44.6 \%$ of the variance in energy drink consumption.

Table 4. Multivariate regression model of personal and environmental correlates of energy drink consumption in university students ( $t$-values, $\beta$-values, Adjusted $R^{2}$ ).

\begin{tabular}{|c|c|c|c|}
\hline$n=425$ & $t$ & $\beta$ & $\operatorname{Adj} R^{2}$ \\
\hline \multicolumn{4}{|l|}{ Control variables } \\
\hline Age & 0.8 & 0.047 & \\
\hline Ethnicity $(0=$ parents from Belgian origin; $1=$ one of parents from foreign origin $)$ & 0.6 & 0.039 & \\
\hline Education mother $(0=$ no diploma higher education; $1=$ diploma higher education $)$ & 1.1 & 0.069 & \\
\hline Education father $(0=$ no diploma higher education; $1=$ diploma higher education $)$ & 0.7 & 0.042 & \\
\hline BMI & 0.7 & 0.045 & \\
\hline \multicolumn{4}{|l|}{ Moderators } \\
\hline Gender $(0=$ male; $1=$ female $)$ & $-2.2 *$ & -1.293 & \\
\hline Residency $(0=$ living at home; $1=$ living in a student residence $)$ & -0.5 & -0.204 & \\
\hline \multicolumn{4}{|l|}{ Personal and environmental correlates } \\
\hline Taste preference & 1.1 & 0.078 & \\
\hline Attitude & -0.5 & -0.040 & \\
\hline Individual subjective norm & -0.9 & -0.086 & \\
\hline Perceived control & $-7.5 * * *$ & -0.820 & \\
\hline Self-efficacy & -0.0 & 0.000 & \\
\hline Perceived benefits & 0.0 & 0.000 & \\
\hline Perceived barriers & -1.4 & -0.134 & \\
\hline Social norm & -1.2 & -0.070 & \\
\hline Social support & $1.8^{\wedge}$ & 0.119 & \\
\hline Modelling & -1.4 & -0.089 & \\
\hline Family rules & $2.2 *$ & 0.198 & \\
\hline Perceived availability & $2.1 *$ & 0.203 & \\
\hline Distance to stores & 0.9 & 0.053 & \\
\hline
\end{tabular}


Table 4. Cont.

\begin{tabular}{cccc}
\hline $\boldsymbol{n}=\mathbf{4 2 5}$ & $\boldsymbol{t}$ & $\beta$ & ${\text { Adj } \boldsymbol{R}^{2}}^{2}$ \\
\hline Moderation effects of gender and residency & & \\
Individual subjective norm x gender & 0.2 & 0.054 & \\
Perceived control x gender & $3.8^{* * *}$ & 1.585 & \\
Perceived control x residency & $1.9^{\wedge}$ & 0.589 \\
$\quad$ Self-efficacy x gender & -0.2 & -0.096 \\
Perceived benefits x residency & -1.5 & -0.389 \\
Perceived barriers x gender & 0.8 & 0.130 \\
Family rules x gender & -1.2 & -0.164 \\
Perceived availability x gender & -1.0 & -0.209 & \\
& & & 0.446 \\
\hline
\end{tabular}

$* p<0.05, * * * p<0.001, \wedge p<0.1, \alpha=0.05$.

\section{Discussion}

The first objective of this study was to assess which personal and environmental factors were related to Belgian university students' soft drink and energy drink consumption. The second objective was to investigate whether these associations were moderated by gender or residency.

Students drank almost half a liter of soft and energy drinks per day, consisting of about $350 \mathrm{~mL}$ of sugar sweetened beverages per day. In contrast, students drank only $17 \mathrm{~mL}$ of sugar containing energy drinks per day. Soft and energy drinks combined, this corresponds to an estimated caloric value of $140 \mathrm{kCal} /$ day, which is less than the $162 \mathrm{kCal} /$ day reported by US students [17]. The latter suggests that Belgian students may drink less sugar sweetened beverages than their US counterparts. This difference might be explained by socio-cultural differences between the European and US beverage culture (free refills in US fast food restaurants). Due to the limited literature in this population no comparison could be made for artificially sweetened beverages or water. Importantly, in comparison to their soft and energy drink intake, Belgian students still consume a larger amount of water $(650 \mathrm{~mL})$ per day.

The fact that Belgian students consume about half a liter of soft and energy drinks per day corresponds with other studies detecting poor dietary habits among university students. Less than $50 \%$ of students in four European countries reported daily consumption of fruits, whereas only $15 \%$ to $32 \%$ of them reported daily vegetable consumption [37]. The same study revealed that $11 \%$ to $77 \%$ of students (depending on the country) consumed fast food at least several times per week [37]. The above suggests that European university students in general fail to meet dietary recommendations.

Individual subjective norm was the strongest correlate of soft drink consumption; the more students living at home were convinced they should minimize their soft drink consumption, the less these students consumed soft drinks. In comparison, no main effect of individual subjective norm was detected in students residing away from home. This may suggest that factors other than individual subjective norm may be more important in the beverage choice making process of students living in a student residence. For instance, previous qualitative research in university students showed that next to taste (which was not significant in the present study), price was mentioned to be one of the most important factors in choosing 
beverages [22,38]. Because students living in a student residence often have budgetary limitations [33], it might be that the beverage choice of students residing away from home is more subject to price than to their individual subjective norm about soft drink consumption. Future experimental studies should investigate if enhancing individual subjective norm towards avoiding soft drinks would indeed decrease students' soft drink consumption. No relationship between individual subjective norm and energy drink consumption was detected.

Perceived behavioral control was the strongest correlate of energy drink consumption. The association between perceived behavioral control and energy drink intake was moderated by both gender and residency. The more male students found it difficult to avoid energy drinks (probably as a consequence of energy drink availability and accessibility), the higher their energy drink consumption. In females, no relationship between perceived control and energy drink intake was detected. In comparison to students living in a student residence, the association between perceived control and energy drink consumption was stronger in students living at home. Furthermore, perceived availability was positively related to energy drink intake. Because energy drink availability may play an important role with regard to (male) students' perceived control over energy drink intake, interventions may have to focus on students' perceived behavioral control and the physical environment at the same time. Students, but also parents and university policy makers are therefore challenged to limit respective home and campus availability of energy drinks and replace them by healthy alternatives such as water. Although not moderated by gender or residency, a similar negative relationship was detected between perceived behavioral control and soft drink consumption. Enhancing self-regulation skills such as behavioral control towards both soft and energy drink consumption may help students to make more healthful decisions and to maintain a healthy lifestyle throughout adulthood $[39,40]$.

Although none of the previous qualitative studies mentioned self-efficacy to be influencing students' beverage consumption, the present study did find that the more students were convinced they could avoid soft drinks in different situations, the lower their soft drink consumption. Hence, strengthening students' self-efficacy towards avoiding soft drinks may decrease their soft drink consumption. Strategies such as self-monitoring (tracking one's own soft drink intake), providing feedback on beverage choices, reviewing behavioral goals, providing rewards, or planning for social support, may effectively increase self-efficacy towards avoiding soft drink consumption [41]. In the present study, self-efficacy was not related to energy drink intake.

Family rules were significantly associated with both soft drink and energy drink consumption. The more male students were/are allowed (by their parents) to drink soft drinks, the higher their soft drink consumption. In comparison, no main effect of family rules were detected in female students. Regarding energy drinks, family rules were positively related to both male and female students' energy drink intake. It has been shown that almost half (48\%) of current users among university students initiated energy drink use between the ages of 16 and 20 years, whereas $42 \%$ of students were only 11 to 15 years old when consuming energy drinks for the first time [20]. Stricter family rules during (or even prior to) adolescence about soft and energy drink intake may help to decrease consumption of soft and energy drinks throughout adolescence and young adulthood, as well as in later life.

Regarding other social environmental factors, modelling was positively related to soft drink consumption in students living at home, but not in students living in a student residence. The more 
these students' partner, parents, friends, or student colleagues consumed soft drinks, the higher their soft drink intake. Although recommendations from family and friends, social settings and peer pressure were mentioned as modes of initiation by Caribbean university students [20], social norm, support and modelling were not associated with energy drink consumption.

The above suggests that multilevel (combining personal with environmental) strategies may be more effective than single-level interventions. So, next to targeting psychological mechanisms, students' (social and physical) environments should be taken into account. In other words, intervention efforts to decrease students' soft and energy drink consumption should also try to provide a favorable environment in which students and their peers are encouraged to make healthy beverage choices. Therefore, different stakeholders (namely students, parents, but also university as well as governmental policy makers) should be involved when designing prevention strategies.

As for the unexplained variance in our analyses, it may be that students' beverage consumption is partly determined by their past consumption habits. Although excluded from the present analyses because of multicollinearity, habit strength was previously detected to be a strong positive correlate of soft drink consumption in adolescents [42]. Furthermore, inspired by Sallis' ecological model to explain health behavior [43], it may be that university students' beverage choices are also influenced by other (meso and macro environmental) factors such as promotion and marketing, market regulations, and policy.

An important strength of this study is that we took possible moderators into account. About half of the significant personal and environmental correlates reported in this study were moderated by gender or residency. This indicates that intervention strategies aiming to decrease soft or energy drink consumption by targeting psychosocial constructs may not be suitable for the total group of university students. Hence, such strategies may have to approach male and female students, as well as students living at or away from home, differently.

Since behavior is dynamic in nature, a static correlational model as such has its limitations [44]. Due to its observational cross-sectional design, the present study was not able to determine causality. Therefore, future controlled trials should investigate whether changes in the above personal and environmental factors can cause changes in students' soft and energy drink consumption. A second limitation is that we used standard portion sizes to estimate soft and energy drink consumption, as well as a self-reporting questionnaire. This may have led to an under- or overestimation of total soft and energy drink consumption. Thirdly, although it is generally recognized that some constructs derived from different psychosocial models overlap (perceived behavioral control, self-efficacy, perceived barriers), we chose to include all measures, facilitating determination of unique contributions of perceived behavioral control over self-efficacy. Because including all measures may reduce the likelihood that any of these items could emerge as significant predictors of behavior, inter-correlation analyses were run so that multicollinearity could be ruled out. Finally, all participating students were volunteers, which may have resulted in a selection bias. It might be that more healthy students participated in this study. However, sample characteristics showed sufficient variance in health related variables, such as BMI, smoking, perceived health and fitness. Unfortunately, we were not able to verify the representativeness of the assessed sample, and, therefore, we have to be cautious with generalizing results to the entire Belgian student population. 


\section{Conclusions}

Interventions aiming at decreasing soft and energy drink consumption in university students should try to enhance behavioral control skills, improve individual subjective norm about beverage use, and strengthen self-efficacy towards avoiding unhealthy beverages. Moreover, these interventions should also focus on the students' environment, by encouraging parents to implement stricter family rules about soft and energy drink intake, but also by targeting beverage use of students' partner, parents and friends, as well as home and campus availability. When designing tailored intervention programs, male and female students as well as students living at home or living in a student residence, may have to be approached somewhat differently. Future research should investigate whether interventions focusing on the above correlates can indeed improve university students' beverage choices.

\section{Acknowledgments}

The authors thank all students participating in this study. We also thank Tim Campine for his contribution in data collection.

\section{Author Contributions}

Tom Deliens, Peter Clarys, Ilse De Bourdeaudhuij and Benedicte Deforche conceived and designed the experiments; Tom Deliens performed the experiments; Tom Deliens and Benedicte Deforche analyzed the data; Tom Deliens wrote the paper.

\section{Conflicts of Interest}

The authors declare no conflict of interest.

\section{References}

1. Malik, V.S.; Popkin, B.M.; Bray, G.A.; Despres, J.P.; Hu, F.B. Sugar-sweetened beverages, obesity, type 2 diabetes mellitus, and cardiovascular disease risk. Circulation 2010, 121, 1356-1364. [CrossRef] [PubMed]

2. Schneider, M.B.; Benjamin, H.J.; Bhatia, J.J.S.; Abrams, S.A.; De Ferranti, S.D.; Schneider, M.B.; Silverstein, J.; Stettler, N.; Thomas, D.W.; McCambridge, T.M.; et al. Clinical report-sports drinks and energy drinks for children and adolescents: Are they appropriate? Pediatrics 2011, 127, 1182-1189.

3. Pereira, M.A.; Odegaard, A.O. Artificially sweetened beverages-do they influence cardiometabolic risk? Curr. Atheroscler. Rep. 2013, 15, 1-6. [CrossRef] [PubMed]

4. Sakurai, M.; Nakamura, K.; Miura, K.; Takamura, T.; Yoshita, K.; Nagasawa, S.Y.; Morikawa, Y.; Ishizaki, M.; Kido, T.; Naruse, Y.; et al. Sugar-sweetened beverage and diet soda consumption and the 7-year risk for type 2 diabetes mellitus in middle-aged Japanese men. Eur. J. Nutr. 2014, 53, 251-258. [CrossRef] [PubMed]

5. Reissig, C.J.; Strain, E.C.; Griffiths, R.R. Caffeinated energy drinks-A growing problem. Drug Alcohol. Depend. 2009, 99, 1-10. [CrossRef] [PubMed] 
6. Heckman, M.A.; Sherry, K.; De Mejia, E.G. Energy drinks: An assessment of their market size, consumer demographics, ingredient profile, functionality, and regulations in the United States. Compr. Rev. Food Sci. F 2010, 9, 303-317. [CrossRef]

7. Burrows, T.; Pursey, K.; Neve, M.; Stanwell, P. What are the health implications associated with the consumption of energy drinks? A systematic review. Nutr. Rev. 2013, 71, 135-148. [CrossRef] [PubMed]

8. Aranda, M.; Morlock, G. Simultaneous determination of riboflavin, pyridoxine, nicotinamide, caffeine and taurine in energy drinks by planar chromatography-multiple detection with confirmation by electrospray ionization mass spectrometry. J. Chromatogr. A 2006, 1131, 253-260. [CrossRef] [PubMed]

9. Elliott, S.S.; Keim, N.L.; Stern, J.S.; Teff, K.; Havel, P.J. Fructose, weight gain, and the insulin resistance syndrome. Am. J. Clin. Nutr. 2002, 76, 911-922. [PubMed]

10. Bray, G.A.; Nielsen, S.J.; Popkin, B.M. Consumption of high-fructose corn syrup in beverages may play a role in the epidemic of obesity. Am. J. Clin. Nutr. 2004, 79, 537-543. [PubMed]

11. Campbell, B.; Wilborn, C.; La Bounty, P.; Taylor, L.; Nelson, M.T.; Greenwood, M.; Ziegenfuss, T.N.; Lopez, H.L.; Hoffman, J.R.; Stout, J.R.; et al. International society of sports nutrition position stand: Energy drinks. J. Int Soc. Sports Nutr 2013, 10, 1. [CrossRef] [PubMed]

12. Diepvens, K.; Westerterp, K.R.; Westerterp-Plantenga, M.S. Obesity and thermogenesis related to the consumption of caffeine, ephedrine, capsaicin, and green tea. Am. J. Physiol. Regul. Integr. Comp. Physiol. 2007, 292, R77-R85. [CrossRef] [PubMed]

13. Rush, E.; Schulz, S.; Obolonkin, V.; Simmons, D.; Plank, L. Are energy drinks contributing to the obesity epidemic? Asia Pac. J. Clin. Nutr. 2006, 15, 242-244. [PubMed]

14. Greer, F.; Hudson, R.; Ross, R.; Graham, T. Caffeine ingestion decreases glucose disposal during a hyperinsulinemic-euglycemic clamp in sedentary humans. Diabetes 2001, 50, 2349-2354. [CrossRef] [PubMed]

15. Crombie, A.P.; Ilich, J.Z.; Dutton, G.R.; Panton, L.B.; Abood, D.A. The freshman weight gain phenomenon revisited. Nutr. Rev. 2009, 67, 83-94. [CrossRef] [PubMed]

16. Vella-Zarb, R.A.; Elgar, F.J. The "freshman 5": A meta-analysis of weight gain in the freshman year of college. J. Am. Coll. Health 2009, 58, 161-166. [CrossRef] [PubMed]

17. West, D.S.; Bursac, Z.; Quimby, D.; Prewitt, T.E.; Spatz, T.; Nash, C.; Mays, G.; Eddings, K. Self-reported sugar-sweetened beverage intake among college students. Obesity 2006, 14, 1825-1831. [CrossRef] [PubMed]

18. Pettit, M.L.; DeBarr, K.A. Perceived stress, energy drink consumption, and academic performance among college students. J. Am. Coll. Health 2011, 59, 335-341. [CrossRef] [PubMed]

19. Attila, S.; Cakir, B. Energy-drink consumption in college students and associated factors. Nutrition 2011, 27, 316-322. [CrossRef] [PubMed]

20. Reid, S.D.; Ramsarran, J.; Brathwaite, R.; Lyman, S.; Baker, A.; Cornish, D.C.; Ganga, S.; Mohammed, Z.; Sookdeo, A.T.; Thapelo, C.K. Energy drink usage among university students in a Caribbean country: Patterns of use and adverse effects. J. Epidemiol. Global Health 2014, 5, 103-116. [CrossRef] [PubMed] 
21. Brunt, A.R.; Rhee, Y.S. Obesity and lifestyle in us college students related to living arrangemeents. Appetite 2008, 51, 615-621. [CrossRef] [PubMed]

22. Block, J.P.; Gillman, M.W.; Linakis, S.K.; Goldman, R.E. "If it tastes good, I'm drinking it": Qualitative study of beverage consumption among college students. J. Adolesc. Health 2013, 52, 702-706. [CrossRef] [PubMed]

23. Hattersley, L.; Irwin, M.; King, L.; Allman-Farinelli, M. Determinants and patterns of soft drink consumption in young adults: A qualitative analysis. Public Health Nutr. 2009, 12, 1816-1822. [CrossRef] [PubMed]

24. Malinauskas, B.M.; Aeby, V.G.; Overton, R.F.; Carpenter-Aeby, T.; Barber-Heidal, K. A survey of energy drink consumption patterns among college students. Nutr. J. 2007, 6, 35. [CrossRef] [PubMed]

25. Verplanken, B.; Orbell, S. Reflections on past behavior: A self-report index of habit strength. $J$. Appl. Soc. Psychol. 2003, 33, 1313-1330. [CrossRef]

26. Vandelanotte, C.; De Bourdeaudhuij, I.; Brug, J. Acceptability and feasibility of an interactive computer-tailored fat intake intervention in belgium. Health Promot. Int. 2004, 19, 463-470. [CrossRef] [PubMed]

27. Bere, E.; Glomnes, E.S.; Velde, S.J.; Klepp, K.I. Determinants of adolescents' soft drink consumption. Public Health Nutr. 2007, 11, 49-56. [CrossRef] [PubMed]

28. Mullie, P.; Clarys, P.; Hulens, M.; Vansant, G. Reproducibility and validity of a semiquantitative food frequency questionnaire among military men. Mil. Med. 2009, 174, 852-856. [CrossRef] [PubMed]

29. Ezendam, N.P.; Evans, A.E.; Stigler, M.H.; Brug, J.; Oenema, A. Cognitive and home environmental predictors of change in sugar-sweetened beverage consumption among adolescents. Br. J. Nutr 2010, 103, 768-774. [CrossRef] [PubMed]

30. Deliens, T.; Clarys, P.; Van Hecke, L.; De Bourdeaudhuij, I.; Deforche, B. Changes in weight and body composition during the first semester at university. A prospective explanatory study. Appetite 2013, 65, 111-116. [CrossRef] [PubMed]

31. Ajzen, I. From Intentions to Actions: A Theory of Planned Behavior; Springer: New York, NY, USA, 1985.

32. Bandura, A. Social Foundations of Thought And Action: A Social Cognitive Theory; Prentice Hall: Englewood Cliffs, NJ, USA, 1986.

33. Deliens, T.; Clarys, P.; De Bourdeaudhuij, I.; Deforche, B. Determinants of eating behaviour in university students: A qualitative study using focus group discussions. BMC Public Health 2014, 14, 53. [CrossRef] [PubMed]

34. Hoge Gezondheidsraad. Maten en gewichten: Handleiding voor een gestandaardiseerde kwantificering van voedingsmiddelen. Available online: www.health.belgium.be/filestore/ 4400388/6545 (accessed on 25 September 2014).

35. Aiken, L.S.; West, S.G. Multiple Regression: Testing and Interpreting Interactions; Sage: Newbury Park, CA, USA, 1991. 
36. Aguinis, H.; Beaty, J.C.; Boik, R.J.; Pierce, C.A. Effect size and power in assessing moderating effects of categorical variables using multiple regression: A 30-year review. J. Appl. Psychol. 2005, 90, 94-107. [CrossRef] [PubMed]

37. El Ansari, W.; Stock, C.; Mikolajczyk, R.T. Relationships between food consumption and living arrangements among university students in four european countries-A cross-sectional study. Nutr. J. 2012, 11, 28. [CrossRef] [PubMed]

38. Yang, C.C.; Chiou, W.B. Substitution of healthy for unhealthy beverages among college students. A health-concerns and behavioral-economics perspective. Appetite 2010, 54, 512-516. [CrossRef] [PubMed]

39. Nelson, M.C.; Kocos, R.; Lytle, L.A.; Perry, C.L. Understanding the perceived determinants of weight-related behaviors in late adolescence: A qualitative analysis among college youth. J. Nutr. Edu. Behav. 2009, 41, 287-292. [CrossRef] [PubMed]

40. Kelly, N.R.; Mazzeo, S.E.; Bean, M.K. Systematic review of dietary interventions with college students: Directions for future research and practice. J. Nutr. Edu. Behav. 2013, 45, 304-313. [CrossRef] [PubMed]

41. Prestwich, A.; Kellar, I.; Parker, R.; MacRae, S.; Learmonth, M.; Sykes, B.; Taylor, N.; Castle, H. How can self-efficacy be increased? Meta-analysis of dietary interventions. Health Psychol. Rev. 2014, 8, 270-285. [CrossRef] [PubMed]

42. Tak, N.I.; Velde, S.J.T.; Oenema, A.; Van der Horst, K.; Timperio, A.; Crawford, D.; Brug, J. The association between home environmental variables and soft drink consumption among adolescents. Exploration of mediation by individual cognitions and habit strength. Appetite 2011, 56, 503-510. [CrossRef] [PubMed]

43. Sallis, J.F.; Owen, N. Ecological models of health behavior, 3rd ed.; Jossey-Bass: San Francisco, CA, USA, 2002.

44. Renner, B.; Hankonen, N.; Ghisletta, P.; Absetz, P. Dynamic psychological and behavioral changes in the adoption and maintenance of exercise. Health Psychol. 2012, 31, 306-315. [CrossRef] [PubMed]

(C) 2015 by the authors; licensee MDPI, Basel, Switzerland. This article is an open access article distributed under the terms and conditions of the Creative Commons Attribution license (http://creativecommons.org/licenses/by/4.0/). 